\title{
SUMBER DAYA MANUSIA \\ DALAM LINGKUNGAN BISNIS GLOBAL KOMPETITIF
}

\author{
Antonius Atosökhi Gea \\ Character Building Development Center, BINUS University \\ Jln. Kemanggisan Ilir III No. 45, Kemanggisan - Palmerah, Jakarta 11480 \\ antoniusgea@binus.edu
}

\begin{abstract}
Global competition in the world of business today and in the future is inevitable. Whether it is liked or not, ready or not, the competition must be faced. There are diference attitudes in facing this situation. Countries which are ready will see it as an opportunity, but it is not always be the same for the developing or poor countries. The increasing of global competition is very widely supported by the development of technology, especially information technology. In this case the Internet occupies the most important part that relies on speed. Although there are many important things in the course of the competition, including the technology, human resources are something very decisive, the determinant key to be actively involved and to win the competition. Therefore, the model of human resource development should be more advanced than before. In this case, the role of Human Resources Management (HRM) is crucial. This section (HRM) should be able to play role to maximize productivity, ensure the quality of employment, and ultimately generates profits through proper management of human resources within the company.
\end{abstract}

Keywords: human, competition, information technology, change, effectiveness

\begin{abstract}
ABSTRAK
Persaingan di tingkat global dalam dunia bisnis sekarang ini dan masa depan tidak bisa dielakkan lagi. Suka tidak suka, siap tidak siap, persaingan tersebut harus dihadapi. Terdapat perbedaan sikap dalam menghadapi perkembangan ini. Negara yang siap memandangnya sebagai kesempatan, tetapi tidak selalu demikian dengan negara berkembang atau negara miskin. Persaingan yang makin ketat dan luas ini sangat ditopang oleh perkembangan teknologi, khususnya teknologi informasi. Dalam hal ini Internet menempati bagian terpenting, dan yang menjadi andalan adalah kecepatan. Walaupun ada banyak hal yang sangat berperan dalam berlangsungnya persaingan, termasuk teknologi, sumber daya manusia merupakan sesuatu yang sangat menentukan. Sumber daya manusia merupakan kunci penentu utama untuk bisa terlibat aktif dan meraih keunggulan memenangkan persaingan. Oleh karena itu, model pengembangan sumber daya manusia harus lebih maju dari sebelumnya. Di sini peran Human Resources Management menjadi sangat krusial. Bagian Human Resource Management harus mampu memainkan peran memaksimalkan produktivitas, menjamin kualitas kerja karyawan, dan akhirnya menghasilkan keuntungan melalui pengelolaan yang baik atas sumber daya manusia dalam perusahaan.
\end{abstract}

Kata kunci: manusia, persaingan, teknologi informasi, perubahan, efektivitas 


\section{PENDAHULUAN}

Dipicu perkembangan pesat di bidang teknologi informasi, khususnya Internet, perusahaan telah mengalami transformasi drastis, bagaikan sebuah revolusi industri baru. Lingkungan kerja sekarang ini ditandai dengan persaingan yang makin tinggi, yang disebabkan banyak faktor. Munculnya globalisasi di banyak bidang, adanya perubahan yang terjadi secara bersamaan di luar perusahaan, perubahan cepat dari teknologi baru, inovasi-inovasi baru dalam hal cara memproduksi, perubahan yang dibawa dari Internet, dan sebagainya, semuanya hal itu telah turut serta menentukan kondisi pengelolaan perusahaan sekarang ini dan masa mendatang (Rahimic \& Car, 2004).

Dalam situasi itu korporasi harus melakukan perubahan dalam banyak hal agar bisa tetap kompetitif dalam persaingan yang makin ketat. Ada banyak hal yang membawa perubahan, namun tidak ada satu hal pun yang melebihi teknologi informasi. Dengan teknologi informasi, khususnya Internet, maka semuanya, mulai dari pegawai yang paling bawah sampai dengan pimpinan paling atas, memiliki kemampuan untuk mendapatkan informasi seluas-luasnya, yang berasal dari mana-mana. Hanya dalam waktu beberapa kedipan mata saja, manusia sudah bisa mengetahui informasi yang datang dari berbagai belahan dunia. Itu berarti korporasi abad ke-21 harus beradaptasi dan menyesuaikan diri dengan manajemen berbasis web. Perusahaan harus siap menghadapi perubahan, bukan stabilitas; membangun kerja sama melalui jaringan, bukan bercokol dengan hierarki yang kaku; membangun kemitraan dan aliansi, bukan merasa cukup dengan dirinya sendiri; mengikuti perkembangan teknologi, dan bukan malah menutup diri.

Berbeda dengan pabrik ratusan tahun lalu, perusahaan sekarang dan masa depan harus merancang produknya dengan menjadikan pelanggannya sebagai rekan dan memberi mereka kesempatan untuk mendesain dan meminta yang persis mereka butuhkan. Kustomisasi massal telah menjurus pada gelombang penciptaan produk dan jasa yang bersifat individual. Ini sebuah tantangan bagi perusahaan karena tidak selalu mudah untuk mengetahui apa dan seberapa banyak keinginan pelanggan itu. Penyampaian produk dan pelayanan yang cepat menjadi sangat penting supaya mereka tidak didahului oleh pesaing atau datang secara bersamaan.

Untuk menghadapi kondisi seperti ini, maka modal intelektual menjadi hal sangat critical bagi kesuksesan sebuah bisnis. Untuk itu perusahaan membutuhkan tenaga SDM yang berkualitas, pemikir yang cerdas. Perusahaan perlu membangun suatu gudang yang dalam penuh talenta, supaya bisa berhasil dalam area yang baru tersebut. Akan tetapi, mendapatkan dan memelihara sumber daya yang bertalenta tinggi membutuhkan lebih dari sekedar membayarkan gaji yang besar. Perusahaan perlu menciptakan suatu budaya dan sistem reward untuk memdapatkan yang terbaik dari para pekerjanya. Kepada mereka tidak lagi ditekankan pendekatan perintah-dan-kontrol yang bersifat hierarkis, melainkan mengembangkan dengan baik sumber daya manusia yang dimiliki dan memberi imbalan yang tepat bagi mereka yang berkontribusi baik, seakan-akan mereka adalah pemilik dari perusahaan itu sendiri (Cascio, 2003).

\section{METODE}

Penelitian ini dilakukan dengan cara library research. Studi pustaka dilakukan dengan menggunakan sumber bacaan yang relevan dan tersedia, yang berkaitan dengan topik yang hendak dikembangkan pemahamannya. Buku atau artikel jurnal yang berkaitan dengan topik yang dibahas dijadikan sebagai sumber bacaan, baik untuk memahami dengan baik buah pikiran dari tokoh yang buah pikirannya menjadi materi bahasan dalam tulisan ini maupun berbagai kajian atau tanggapan 
penting dan serius atas buah pikiran tersebut. Tulisan ini dikembangkan dari berbagai sumber bacaan yang digunakan, termasuk memberi tanggapan atau komentar kritis, khususnya pada bagian simpulan.

\section{HASIL DAN PEMBAHASAN}

Banyak ilmuwan yang telah mendefinisikan globalisasi dari berbagai sudut pandang. Salah satu rumusan yang bagus adalah, "globalisation means the growing interdependence and interconnectedness of the modern world," (Zhou, 2010). Definisi ini sangat kena mengingat globalisasi adalah sesuatu yang terkait dengan politik, teknologi dan budaya, dan juga ekonomi (Giddens dalam Mohan, 2000). Globalisasi terkait dengan saling terhubungnya berbagai belahan dunia, yang pasti menyentuh dimensi politik suatu bangsa, perkembangan teknologi dan budayanya serta keadaan ekonomi yang saling memengaruhi di antara bangsa-bangsa.

Semula, globalisasi dimengerti sebagai kemampuan untuk dengan mudah menjual produk ke berbagai negara. Kemudian globalisasi dimengerti sebagai hadirnya pabrik suatu perusahaan di berbagai negara. Akan tetapi ke depan, globalisasi lebih dilihat dalam kaitannya dengan talenta dan sumber daya, khususnya intellectual capital-yang mereka bisa ditemukan, termasuk juga kemampuan menjual produk dan servis, di mana saja di dunia. Sebagai contoh, perusahaan Amerika, program software dibuat di Sri Lanka, insinyur dari Jerman, dan pabrik berada di China, dsb. (Cascio, 2003).

Secara umum diakui bahwa globalisasi menciptakan berbagai kesempatan dan juga risiko yang tidak dapat diprediksi sebelumnya. Akan tetapi (negara) dunia ketiga, secara keseluruhan berpendapat bahwa kesempatan itu mutlak bagi negara kaya saja, seraya risiko lebih bagi negara miskin (Zhou, 2010). Dalam hal ini, pemerintahan Inggris mengklaim "itu tergantung pada pilihan kebijakan yang diadopsi oleh pemerintah, lembaga-lembaga internasional, sektor-sektor swasta serta masyarakat madani/sipil secara keseluruhan," (Zhou, 2010). Jika dikelola dengan bijaksana, kekayaan baru akan diciptakan oleh globalisasi, dan akan tercipta kesempatan untuk mengangkat berjuta-juta orang miskin dunia keluar dari kemiskinan. Akan tetapi jika dikelola secara buruk, hal tersebut akan membawa pada suasana termarjinalkan dan kemiskinan.

Dari semua faktor yang memengaruhi globalisasi, sikap dari pemerintah suatu negara terhadap globalisasi ikut memengaruhi proses globalisasi itu. Jika pemerintahan percaya akan kesempatan yang diciptakan oleh globalisasi, ia akan melakukan segala usaha untuk mendorong makin bergulirnya globalisasi itu. Sebaliknya, jika suatu pemerintahan percaya akan risiko yang dibawa serta oleh globalisasi, hal itu akan membawa pada salah sikap berikut, yakni segan menyertakan diri dengan globalisasi atau melawan globalisasi. Dalam kaitan dengan itu, maka dirasa perlu melihat perbedaan konsep tentang globalisasi yang dianut oleh negara yang berbeda, serta baik-buruknya konsep tersebut dilihat dari berbagai aspek (Zhou, 2010).

Kebijakan positif yang sebaiknya diambil, Aziz dan Westcott berpendapat bahwa hal yang perlu dijalankan adalah adanya saling melengkapi antara tiga hal terpisah yang dibutuhkan dalam suatu kombinasi, yakni: perdagangan bebas (terbuka), stabilitas ekonomi makro, dan keterlibatan relatif rendah pemerintah atas kegiatan ekonomi (Mosley, 2000). Tidak ada satu pun dapat menolak bahwa globalisasi akan menciptakan risiko dan tantangan yang tidak dapat diprediksi sebelumnya, seperti yang diakui Tony Blair: "What is called globalisation is changing the nature of the nation-state as power becomes more diffuse and borders more porous. Technological change is already reducing the power and capacity of government to control its domestic economy free from external influence," (Mohan, 2000:121). Akan tetapi untuk negara miskin, risiko adalah sesuatu yang menghancurkan, yang datang setiap saat, yang negara kaya kelihatannya tidak terlalu menghiraukannya. 


\section{Globalisasi - Terkait dengan Kecepatan (speed)}

Pada era globalisasi abad ke-21 semua kerja dapat dilaksanakan bersamaan, dan Internet adalah alat yang menjamin terwujudnya kecepatan itu. Hal demikian berarti perusahaan dengan model lama, yang berorientasi proses, harus berubah secara radikal. Tidak ada waktu yang cukup untuk musyawarah tentang siklus produksi hingga masalah turnover karyawan. Pemerintahan Inggris telah dengan jelas menyimpulkan hal yang merupakan kekuatan pendorong bagi globalisasi, yakni: "The increased ease of movement of goods, services, capital, people and information across national boarders is rapidly creating a single global economy. The process is driven by technological advance and reduction in the cost of international transaction," (Zhou, 2010).

Perusahaan abad ke-21 tidak akan memiliki satu bentuk ideal. Beberapa perusahaan berjalan dengan baik, semua bergantung pada jaringan supplier, pabrik, dan distributor untuk bertahan hidup. Namun perusahaan yang paling sukses umumnya berbentuk sangat kecil dan spesial. Sementara yang lainnya berbentuk raksasa dalam hal ukuran, cakupan, dan kompleksitasnya. Perubahan-perubahan tersebut dapat dilihat pada Tabel 1 berikut.

Tabel 1 Pandangan Berbeda tentang Bentuk Perusahaan

\begin{tabular}{lll}
\hline \multicolumn{1}{c}{ Characteristic } & \multicolumn{1}{c}{$\mathbf{2 0}^{\text {th }}$ Century } & \multicolumn{1}{c}{$\mathbf{2 1}^{\text {st }}$ Century } \\
\hline Organization & The pyramid & The web or network \\
Focus & Internal & External \\
Style & Structured & Flexible \\
Source of strength & Stability & Change \\
Structure & Self-sufficiency & Interdependencies \\
Resources & Atoms-phisical assets & Bits-Information \\
Operations & Vertical integration & Virtual integration \\
Products & Mass production & Mass customization \\
Reach & Domestic & Global \\
Financials & Quarterly & Real time \\
Inventories & Months & Hours \\
Strategy & Top down & Bottom up \\
Leadership & Dogmatic & Inspirational \\
Workers & Employees & Employees and free agents \\
Job expectations & Security & Personal growth \\
Motivation & To compete & To build \\
Improvements & Incremental & Revolutionary \\
Quality & Affordable best & No compromise \\
\hline
\end{tabular}

(Sumber: Cascio, 2003:5)

Sangat jelas bahwa perusahaan-perusahaan kecil dan menengah memainkan peran penting dalam perkembangan ekonomi suatu negara. Kecenderungan pertumbuhan ekonomi sekarang ini dan laju perkembangan industri telah membuat Malaysia sebagai salah satu negara dengan ekonomi paling terbuka di dunia. Bersama dengan Ninth Malaysia Plan (2006-2010), pemerintah Malaysia merancang dan mengembangkan perusahaan-perusahaan berskala kecil dan menengah untuk membantu perusahaan-perusahaan tersebut mendapatkan tantangan-tantangan bisnis baru dalam lingkungan bisnis persaingan global. Tidak ada keraguan lagi bahwa kegiatan ekonomi bergerak dalam arahan globalisasi. Sistem produksi dan distribusi makin berkembang mendunia. Aturan penting yang dijalankan oleh perdagangan internasional dalam hubungan berbagai negara menjadi lebih jelas. Globalisasi menciptakan struktur dan relasi baru, dengan hasilnya bahwa keputusan dan tindakan bisnis di salah satu bagian dari dunia memiliki konsekuensi berarti di tempat lain. Digarisbawahi dan ditekankan kembali bahwa kecenderungan globalisasi adalah perubahan pesat di lingkungan teknologi, khususnya dalam proses informasi dan telekomunikasi. Perubahan dalam hal telekomunikasi dan 
kemampuan memproses data secara cepat dan akurat membuat berbagai pihak mampu melakukan koordinasi penelitian, operasi produksi dan perdagangan di seluruh dunia. Komunikasi dalam waktu bersamaan membuat pertukaran dan transaksi keuangan dapat dilakukan dalam waktu dua puluh empat jam sehari (Muhammad, et al., 2010).

\section{Perusahaan Terkait dengan Manusia}

Perusahaan dikelola dan diisi oleh manusia. Tanpa manusia, perusahaan tidak mungkin ada. Tentu saja tantangan, kesempatan, dan juga frutrasi dalam menciptakan dan mengelola perusahaan sering kali berasal dari masalah-masalah terkait manusia yang muncul di antara mereka. Sebaliknya, masalah-masalah yang muncul terkait manusia ini sering kali timbul dari kepercayaan keliru bahwa manusia itu semuanya sama, sehingga mereka bisa diperlakukan secara sama. Tidak ada kemajuan yang bisa dicapai dari pemahaman seperti ini. Seperti kepingan salju, tidak ada dua orang yang sama sekali sama, dan setiap orang berbeda secara fisik dan kejiwaan dari siapa pun juga. Perbedaan ini menuntut perhatian sehingga setiap pribadi dapat memaksimalkan potensi mereka, sehingga perusahaan dapat memaksimalkan efektivitasnya, dan masyarakat secara keseluruhan dapat lebih bijaksana dalam memandang dan memperlakukan sumber daya manusianya.

Jika manusia merupakan hal sangat penting bagi suksesnya sebuah bisnis pada abad ke-21, hal yang perlu dilakukan oleh perusahaan, menurut John T. Chambers, CEO Cisco Systems, Inc.,: "The reason people stay at a company is that it's a great place to work. It's like playing on a great sport s team. Really good players want to be around other really good players. Secondly, people like to work for good leadership. So creating a culture of leader that people like is key. And the third is, are you working for a higher purpose than an IPO or a paycheck? Our higher purpose is to change the way the world works, lives, and plays," (Cascio, 2003).

Jadi, jika perusahaan menghasilkan keuntungan melalui manusia, hal yang harus dilakukan paling tidak ada tujuh hal yang perlu diperhatikan, yaitu: employment security, selective hiring, selfmanaged teams and decentralization are basic elements of organization design, comparatively high compensation contingent on organizational performance, extensive training, reduced differences in status, sharing of information. Mengelola manusia merupakan peran sangat penting dari setiap manajer dalam perusahaan. Para manajer bertanggung jawab atas tersedianya sumber daya yang mereka butuhkan, seperti: bahan baku, modal, dan manusia. Ketika mereka berurusan dengan pengelolaan manusia, mereka harus memerhatikan beberapa tingkatan yang meliputi lima kegiatan berikut: staffing, retention, development, adjustment, dan managing change. Staffing adalah mendata kebutuhan pekerjaan di dalam organisasi; menentukan jumlah tenaga kerja beserta kemampuan dan keterampilan yang diperlukan sesuai pekerjaan yang ada; merekrut, menyeleksi, dan mempromosikan kandidat yang qualified. Retention adalah memberi imbalan kepada karyawan berprestasi, memastikan hubungan kerja yang harmonis antara pekerja dan pimpinan, memelihara keselamatan dan kesehatan kerja. Development adalah meningkatkan kompetensi karyawan atas pekerjaan mereka dengan cara memperbaiki knowledge, skill dan ability mereka serta berbagai kemampuan lain yang butuh untuk dikembangkan. Adjustment adalah berusaha agar kebijakan manajemen sumber daya manusia bisa berjalan dengan baik, seperti: penerapan kedisiplinan, pengaturan pembiayaan, dsb. Managing change adalah meningkatkan kemampuan organisasi dalam mengantisipasi dan merespons perubahan/perkembangan yang terjadi di dalam dan di luar lingkungan organisasi/perusahaan, dan memampukan para pekerja untuk menghadapi perubahan-perubahan yang ada.

Hal-hal yang bersifat teknis, ekonomi, dan perubahan-perubahan sosial telah memengaruhi peningkatan ketergantungan perusahaan terhadap sumber daya manusia dalam usaha mencapai tujuan mereka. Sumber daya manusia dianggap sebagai faktor paling penting bagi perusahaan untuk meraih sukses. Lalu kualitas dan motivasi karyawan merupakan hal penting, khususnya untuk mencapai posisi saing, terutama bagi perusahaan kecil dan menengah, karena mereka tidak bisa membangun daya saing mereka atas dasar volume atau ukuran besar perusahaan. Itulah sebabnya perusahaan yang 
sukses menempatkan seleksi, kualifikasi, dan motivasi dari karyawan mereka sebagai hal yang sangat penting. Di sini fungsi Human Resource Management merupakan fungsi manajemen strategi, yang di dalamnya para manajer tingkat tinggi berperan menciptakan kondisi para manajer tingkat rendah untuk pengembangan sumber daya manusia ke tingkat kualitas lebih tinggi (Rahimic \& Car, 2004).

Umumnya, kegiatan staffing, retention, development, dan adjustment merupakan tanggung jawab khusus dari Departemen Sumber Daya Manusia. Akan tetapi, tanggung jawab ini merupakan inti tugas dari setiap manajer dalam organisasi/perusahaan; dan karena jajaran manajer memiliki otoritas (jaminan kuasa secara organisasi untuk memengaruhi tindakan dan perilaku dari pekerja yang mereka pimpin), mereka memiliki pengaruh jelas untuk mendorong para pekerja agar bertindak dan berperilaku sesuai yang diharapkan. Hal ini secara tidak langsung membawa dua implikasi: (1) tujuan luas dari Human Resource Management untuk mengoptimalkan kegunaan (misalnya produktivitas) dari seluruh pekerja di dalam organisasi, dan (2) tujuan khusus dari Human Resource Management untuk memberdayakan para manajer garis depan agar lebih mampu dalam mengelola para pekerja mereka secara lebih efektif. Human Resource Management berperan mewujudkan tujuan khusus ini melalui kebijakan awal dan perumusan, nasihat, servis, dan kontrol dalam suatu komunikasi intim dan koordinasi hangat dengan jajaran manajer lain dalam organisasi/perusahaan. Untuk memastikan hal ini, setiap tanggung jawab Human Resource Management dibagi menjadi departemen Human Resource dan line mamagers. Ilustrasi mengenai hal ini dapat dilihat pada Tabel 2 berikut.

Tabel 2 Tugas HRM dan Tanggung Jawab Line Manager dan HR Department

\begin{tabular}{|c|c|c|}
\hline Activity & Line Management Responsibility & HR Department Responsbility \\
\hline $\begin{array}{l}\text { Staffing: } \\
\text { mendata kebutuhan pekerjaan di dalam } \\
\text { organisasi; menentukan jumlah tenaga } \\
\text { kerja beserta kemampuan skill yang } \\
\text { diperlukan sesuai pekerjaan yang ada; } \\
\text { merekrut, menyeleksi, dan } \\
\text { mempromosikan kandidat yang qualified }\end{array}$ & $\begin{array}{l}\text { Providing data for job analysis and } \\
\text { minimum qualification; integrating } \\
\text { strategic plans with HR plans at the } \\
\text { unit level (seperti department, } \\
\text { division); inteviewing candates, } \\
\text { integrating information collected by } \\
\text { the HR department, making final } \\
\text { decision on entry-level hires and } \\
\text { promotions }\end{array}$ & $\begin{array}{l}\text { Job analysis, human resource } \\
\text { planning, recruitment; compliance } \\
\text { with civil rights laws and regulations; } \\
\text { application blanks, written test, } \\
\text { interviews, background } \\
\text { investigations, reference checks, } \\
\text { phyisical examinations }\end{array}$ \\
\hline $\begin{array}{l}\text { Retention: } \\
\text { memberi imbalan kepada karyawan } \\
\text { berprestasi, memastikan hubungan kerja } \\
\text { yang harmonis antara pekerja dan } \\
\text { pimpinan, memelihara keselamatan dan } \\
\text { kesehatan kerja }\end{array}$ & $\begin{array}{l}\text { Fair treatment of employee open } \\
\text { comunication, face-to-face resolution } \\
\text { of conflict, promotion of teamwork, } \\
\text { respect for the dignity of each } \\
\text { individual, pay increases based on } \\
\text { merit }\end{array}$ & $\begin{array}{l}\text { Compensation and benefits, employee } \\
\text { relations, health and safety, employee } \\
\text { services }\end{array}$ \\
\hline $\begin{array}{l}\text { Development: } \\
\text { meningkatkan kompetensi karyawan } \\
\text { atas pekerjaa mereka dengan cara } \\
\text { memperbaiki knowledgr, skill dan ability } \\
\text { mereka serta berbagai kemampuan lain } \\
\text { yang butuh untuk dikembangkan }\end{array}$ & $\begin{array}{l}\text { On-the-job training, job enrichment, } \\
\text { coaching, applied motivational } \\
\text { strategies, performance feedback to } \\
\text { subordinates }\end{array}$ & $\begin{array}{l}\text { Development of legally sound } \\
\text { performance management system, } \\
\text { morale surveys, technical training; } \\
\text { management and organizational } \\
\text { development; career planning, } \\
\text { counseling; HR research }\end{array}$ \\
\hline $\begin{array}{l}\text { Adjustment: } \\
\text { berusaha agar kebijakan MSDM bisa } \\
\text { berjalan dengan baik, seperti: penerapan } \\
\text { kedisiplinan, pengaturan pembiayaan, } \\
\text { dsb }\end{array}$ & $\begin{array}{l}\text { Discipline, discharge, layoffs, } \\
\text { transfers }\end{array}$ & $\begin{array}{l}\text { Investigation of employee } \\
\text { complaints, outplecement services, } \\
\text { retirement counseling }\end{array}$ \\
\hline $\begin{array}{l}\text { Managing Change: } \\
\text { meningkatkan kemampuan organisasi } \\
\text { dalam mengantisipasi dan merspons } \\
\text { perubahan/perkembangan yang terjadi di } \\
\text { dalam dan di luar lingkungan organisasi, } \\
\text { dan memampukan para pekerja untuk } \\
\text { menghadapi perubahan-perubahan yang } \\
\text { ada. }\end{array}$ & $\begin{array}{l}\text { Provide a vison of where company or } \\
\text { unit is going and the resources to } \\
\text { make the vision a reality }\end{array}$ & $\begin{array}{l}\text { Provide expertise to fasilitate the } \\
\text { overall process of managing change }\end{array}$ \\
\hline
\end{tabular}




\section{Tampilan Lingkungan Persaingan Bisnis}

Secara sederhana, globalisasi bisnis merujuk pada pergerakan bebas modal, barang, jasa, ide, informasi, dan orang melintasi sekat-sekat nasional. Pasar di setiap negara telah menjadi ajang peperangan sengit. Pesaing domestik dan asing berkelahi untuk merebut pangsa pasar.

\section{Implikasi Globalisasi terhadap HRM}

Ketika setiap ekonomi berkembang menjadi global, daya saing negara yang paling penting adalah skills dan pembelajaran banyak dari pekerjanya. Secara definisi, globalisasi membuat hal ini jadi kebenaran. Sesungguhnya, semua negara berkembang dapat mendesain, memproduksi, dan mendistribusikan barang dan jasa dengan mutu dan kecepatan yang sama. Setiap faktor dari produksi, selain keterampilan tenaga kerja, dapat diduplikasikan di mana pun di dunia. Modal yang ada bergerak bebas melintasi sekat-sekat nasional, mencari biaya termurah. Berbagai pabrik dapat didirikan di mana-mana. Teknologi terkini bergerak dari komputer di suatu negara, melewati jaringan satelit di udara, dan kembali turun ke komputer di negara lain, semua dengan kecepatan dorongan elektronik. Semua dapat bergerak: modal, teknologi, bahan baku mentah, informasi, semuanya, kecuali satu hal, bagian paling penting, unsur satu-satunya yang unik di setiap negara atau perusahaan, yaitu tenaga kerja. Tenaga kerja yang ahli dan terampil dalam mengerjakan hal-hal yang kompleks akan membuat perusahaan berdaya saing dan dapat menarik investasi asing. Dalam kenyataannya, terbentuk suatu siklus yang baik: pekerja yang terlatih dengan baik menarik perusahaan global, yang menanamkan dan memberikan pekerja itu pekerjaan baik; dan pekerjaan baik, sebaliknya, memberikan pelatihan dan pengalaman tambahan bagi pekerja itu sendiri.

Jenis pekerjaan yang perkembangannnya sangat pesat di Amerika adalah yang terkait dengan komputer. Menurut data dari Bureau of Labor Statistics (U.S. Bureau of Labor Statistics, 2005) persentasi pekerja yang bekerja di dunia industri menurun tajam, tinggal 20\%, merupakan level paling rendah sejak 1850. Sebaliknya modal yang dikeluarkan untuk pengembangan dan penggunaan teknologi informasi telah naik tiga kali lipat sejak 1960, dari 10\% menjadi lebih dari 35\%. Dalam ekonomi kreatif, hal paling penting bukanlah software atau musik, melainkan intellectual capital yang ada dalam diri setiap orang. Masalahnya, jika aset bersifat fisik, pemilik modal benar-benar bisa memilikinya; sedangkan jika aset vital adalah manusia, tidak akan benar-benar bisa memilikinya. Maka hal terbaik dilakukan oleh perusahaan agar tenaga kerja terbaik betah adalah dengan menciptakan lingkungan dan suasana kerja yang baik. Ini merupakan tantangan bagi manajemen sumber daya manusia.

\section{Pengaruh Kuat Teknologi Baru terhadap HRM}

Bagian paling sentral menggunakan teknologi di dalam Human Resource Management adalah Human Resources Information System (HRIS). Sebagai teknologi, yang terintegrasi dengan aktivitas Human Resource, pengelolaan secara professional terhadap sumber daya manusia merupakan perbaikan dalam hal merespons waktu dan efisiensi laporan informasi yang tersedia. Ada banyak vendor menawarkan aplikasi HRIS yang memuat aneka manfaat pendataan pelaksanaan kerja, waktu dan laporan kehadiran, pelatihan dan pengembangan, pembayaran, rencana pensiun, dan survei karyawan. Sistem demikian mudah digunakan untuk memasukkan berbagai aplikasi yang dapat diambil sewaktu diperlukan, seperti laporan berkala, rencana suksesi, rencana strategi, perencanaan karier, dan evaluasi kebijakan dan praktik Human Resource. Dalam hal ini HRIS yang digunakan sekarang merupakan alat bagi kontrol manajemen dan pengambilan keputusan, jadi sangat diperlukan dan membantu sekali.

Terkait dengan penggunaan teknologi informasi, yang terjadi adalah Internet telah mengubah banyak hubungan antara konsumen dan produsen dalam nuansa yang tidak pernah dibayangkan 
sebelumnya. Internet bukan sekadar saluran lain dari marketing, bukan sekadar sarana periklanan, bukan sekadar untuk transaksi cepat. Internet adalah fondasi untuk suatu keberadaan industri baru. Internet telah memberikan power kepada konsumen. Penggunaan web telah secara mendasar mengubah banyak harapan konsumen, baik itu menyangkut alat yang menyenangkan hidup, kecepatan, perbandingan harga, maupun pelayanan (Cascio, 2003).

\section{Perubahan Demografi dan Meningginya Keragaman Budaya}

Para pekerja mengahadapi masalah kronik kekurangan bantuan untuk mengatasi kekurangan keterampilan mereka. Jumlah orang yang bisa bekerja berubah cepat dan banyak (jumlah yang berpendidikan, wanita pekerja, dsb). Implikasi penting dari kecenderungan ini bagi para manajer adalah pertama, kekurangan asupan tenaga kerja berkualitas membuat pencarian untuk mendapatkan karyawan menjadi prioritas utama, dan kedua, tugas-tugas mengelola perbedaan budaya di antara para pekerja, meningkatkan motivasi dan usaha dari para pekerja yang banyak sekali variasinya. Kedua hal ini akan selalu menghadirkan tantangan berkelanjutan bagi manajemen. Perusahaan yang mencapai kemajuan adalah yang berhasil merangkul demografi baru ketimbang menentangnya.

\section{Respons Perusahaan terhadap Realitas Persaingan Baru}

Pendekatan pada dunia industri selama abad ke-19 dan ke-20 didominasi oleh tiga "C" command, control, compartmentalization. Namun sekarang pada abad ke-21 kecenderungannya berubah menjurus pada bentuk-bentuk: perusahaan berukuran kecil yang mempekerjakan sedikit karyawan; dari bentuk hierarki vertikal yang tinggi ke network specialist; para teknisi, bergerak dari posisi sebagai spesialis reparasi komputer $\rightarrow$ ke terapis radiasi, menempatkan pekerja manufaktur menjadi pekerja elit; membayar lebih besar bukan pada jabatan atau posisi, melainkan pada nilai jual dari skill-nya; dari menyediakan produk $\rightarrow$ ke menyediakan servis; mengunakan tenaga outsourcing untuk pekerjaan yang bukan inti; merumuskan ulang pekerjaan itu sendiri: constant learning, more higher-order thinking, less nine-to-five mentality.

Merespons perubahan-perubahan ini, banyak perusahaan melakukan satu atau lebih dari halhal berikut: mengembangkan bentuk baru dari perusahaan, restrukturisasi (termasuk dalam hal ukuran), mengadopsi prinsip-prinsip dari TQM, merekayasa ulang proses-proses kerja mereka, membangun fleksibilitas dalam hal jadwal dan aturan kerja. Bentuk baru organisasi dari perubahanperubahan ini adalah virtual organization, kelompok para ahli datang bersama untuk mengejakan suatu proyek. Mereka bekerja kapan saja, di mana saja, dengan ruang nyata atau ruang maya. Berbagai sarana yang tersebar luas dari e-mail, teleconference, faksimile, dan intranet memungkinkan hal-hal ini terjadi.

Dalam hal melakukan restrukturisasi, bisa dalam bentuk menjual atau membeli pabrik atau merek dagang, atau memberhentikan karyawan. Perampingan perusahaan, suatu rencana pengurangan posisi dan kerja, telah membawa pengaruh bagi organisasi, manajer pada banyak tingkat, karyawan, pasar tenaga kerja, pelanggan dan pemegang saham. Sementara revolusi TQM yang dimulai 1980-an berdasar pada prinsip statistic quality control dalam proses manufaktur, yang dikembangkan oleh W. Edwards Deming. Motorola, Xerox, dan Ford adalah pionir dalam hal penerapan prinsip ini di AS. TQM adalah serangkaian prinsip dan tindakan yang inti gagasannya adalah mengerti kebutuhan pelangan, melakukan hal yang benar pada tahap pertama, dan berjuang melakukan perbaikan terus menerus.

Reengineering, muncul setelah TQM, pendekatannya lebih komprehensif dalam hal mendesain ulang proses dalam bisnis. Ini merupakan pemikiran ulang sangat mendasar dan penataan ulang yang radikal atas proses bisnis untuk mencapai perbaikan yang dramatis dalam hal biaya, kualitas, dan kecepatan. Isu untuk HR adalah diperlukan bahwa manajer menciptakan suatu lingkungan kerja dan budaya organisasi yang lebih merangkul ketimbang menentang perubahan. 
Dalam fleksibilitas, waktu adalah komoditas sangat berharga bagi seorang karyawan. Mereka menginginkan fleksibilitas dalam mengontrol waktu mereka, tentang di mana, kapan, dan bagaimana mereka kerja. Mereka butuh keseimbangan antara kerja dan waktu senggang. Fleksibiltas dalam hal penjadwalan adalah kunci bagi perusahaan untuk bisa mendapatkan pekerja berkualitas dalam pasar lowongan kerja yang hangat/panas.

\section{Perilaku Pekerja dan Strategi Sumber Daya Manusia}

Strategi kompetitif harus dikembangkan oleh perusahaan. Perusahaan harus bersaing meraih pangsa pasar untuk mendapatkan keunggulan kompetitif, dapat dilakukan dengan berbeda cara, termasuk mengenai penentuan tekanan, seperti: inovasi, peningkatan kualitas, pengurangan biaya, atau kecepatan. CEO membutuhkan pimpinan HR yang memiliki perasaan jernih tentang arah strategi, mengetahui pelayanan yang dibutuhkan oleh bisnis, dan memahami dengan baik usaha-usaha yang dilakukan menghadapi perubahan organisasi. Strategi HRM dimaksudkan untuk mengajak setiap orang mulai dari pimpinan paling atas sampai level paling bawah untuk melakukan sesuatu menerapkan secara efektif strategi bisnis, menyangkut hal berikut. Pertama, innovation strategy, menyeleksi, dan mempromosikan orang-orang yang punya keterampilan yang tinggi, juga berinvestasi besar bagi pengembangan SDM, lalu mengembangkan produk dan jasa yang berbeda dengan pesaing. Kedua, quality-enhancemen strategy, berfokus pada pelayanan jangka panjang, meningkatkan kerja sama, berikap independen, berfokus pada tujuan organisasi, meningkatkan kualitas produk barang dan pelayanan, dan menyampaikannya sesuai dengan harapan pelanggan. Ketiga, cost-reduction strategy, biaya paling sedikit atas produk dan pelayanan yang disampaikan, termasuk pengurangan jumlah karyawan, menurunkan level gaji, menggunakan pekerjaan part-time, serta mengubah aturan kerja. Keempat, speed strategy, menjadi inovator, produsen, distributor dan penanggap tercepat atas umpan balik dari pelanggan, menyeleksi dan mengangkat orang yang punya keterampilan tinggi, yang memiliki komitmen pada speed management (Cascio, 2003).

Pengelolaan sumber daya manusia yang efektif dalam suatu perusahaan akan berpengaruh pada produktivitas, kualitas kerja, dan dampaknya pada sikap terhadap perusahaan. Dalam hal produktivitas perusahaan yang lebih produktif memiliki posisi saing yang lebih baik karena unit costnya lebih rendah. Memperbaiki produktivitas bukan berarti bekerja lebih berat, melainkan bekerja lebih smart; bisa bekerja dengan sedikit orang, sedikit uang, sedikit waktu. Dalam hal kualitas kerja adanya promosi dari dalam, supervisi yang demokratis, melibatkan para pekerja, kondisi keamanan kerja. Para karyawan merasa nyaman, ada rasa puas, dan mereka bisa bertumbuh dan berkembang selayaknya. Dampak dari semua itu adalah para pekerja tidak meninggalkan perusahaan tempat mereka bekerja. Mereka merasa dibutuhkan dan mereka bisa mengembangkan karier di tempat itu.

\section{SIMPULAN}

Manusia adalah komponen utama dalam sebuah bisnis; dan pengelolaan manusia (HRM) adalah bagian paling penting tugas setiap manajer. Hal itu merupakan tanggung jawab khusus dari departemen HRM. Dalam kenyataan, penggunaan istilah Strategic HRM merujuk pada kemungkinan paling bijaksana menjadikan manusia secara hormat pada pencapaian fokus strategi dari perusahaan. HRM meliputi lima wilayah utama: staffing, retention, development, adjustment, dan managing change. Semuanya itu membentuk sistem HRM, yang membentuk suatu jaringan komponen yang saling terhubung. Fungsi HRM adalah tanggung jawab dalam hal memaksimalkan produktivitas, kualitas kerja, dan keuntungan melalui pengelolaan yang baik terhadap sumber daya manusia.

Suasana persaingan bisnis pada abad ke-21 ditandai oleh faktor seperti perubahan tenaga kerja dalam suatu tempat kerja yang high-tech, yang menuntut dan mengganjar orang yang berketerampilan 
baik, dan meningkatkan persaingan global di hampir semua sektor ekonomi. Dalam menanggapi hal itu, bentuk-bentuk baru organisasi atau perusahaan, seperti korporasi virtual, tempat kerja maya, dan beberapa penyesuaian lain dalam perusahan, perlu ditampakkan. Bentuk baru menerapkan pendistribusian ulang kuasa, partisipasi yang makin besar dari para pekerja (lebih dalam bentuk kelompok kerja). Perusahaan-perusahaan juga ditata dan direkayasa ulang, menerapkan TQM, membangun fleksibiltas dalam hal jadwal kerja supaya mendukung strategi mereka. Strategi yang perlu dilakukan berupa inovasi, peningkatan kualitas, penghematan biaya, dan/atau kecepatan.

Satu dari tuntutan yang agak serius dihadapi sekarang ini adalah perbaikan produktivitas. Perbaikan produktivitas menghasilkan yang lebih baik dari yang didapatkan, melakukan yang terbaik dari/dengan yang dimiliki, bekerja lebih smart bukan lebih keras. Walaupun demikian, meningkatkan produktivitas tidak menghalangi kualitas kerja yang tinggi. Kualitas kerja di sini merujuk pada persepsi pekerja tentang kenyamanan fisik dan psikis mereka dipekerjaan. Hal itu termasuk memberikan para pekerja kesempatan untuk membuat keputusan tentang pekerjaan mereka, penataan tempat kerja mereka, serta yang mereka butuhkan untuk memproduksi atau menyampaikan pelayanan secara lebih efektif. HR profesional dapat membantu dengan cara melayani sebagai partner, innovator, collaborator, dan fasilitator perubahan.

\section{DAFTAR PUSTAKA}

Cascio, W. F. (2003). Managing Human Resources: Productivity, Quality of Work Life, Profits, 6th Edition. New York: McGraw-Hill.

Mohan, G. (2000, Apr.). Dislocating Power, Politics and Global Change. Geography.

Mosley, P. (2000). Globalisation, economic policy and convergence. The World Economy, 23(5).

Muhammad, M. Z., Char, A. K., Rushdan, M. bin Yasoa., Hassan, Z. (2010, Jan). Small and Medium Enterprises (SMEs) competing in the global business environment: a case of Malaysia. International Business Research, 3(1), 66-75. http://www.ccsenet.org/journal/index.php/ibr/article/viewFile/3893/3945

Rahimic, Z., \& Car, M. (2004). The quality of Human Resources Management and competitive advantage of the small and the middle companies in Bosnia and Herzegovina. An Enterprise Odyssey. International Conference Proceedings, 1463-1473. Zagreb: University of Zagreb, Faculty of Economics and Business. (Jun 17-Jun 19, 2004)

Zhou, Y. (2010, Jul). Manipulation of globalization. Asian Social Science, 6(7), 171-175. http://ccsenet.org/journal/index.php/ass/article/view/6570/5161 